\title{
A review of culturally tailored interventions to reduce cardiovascular disease in South Asians
}

\author{
Rozmin Jiwani*, Shane Gerry and Darpan Patel \\ The UT Health at San Antonio, USA
}

\begin{abstract}
South Asians (SA) in the United States suffers from earlier onset of cardiovascular disease (CVD) and have a 3 to 5 -fold increased risk of CVD mortality compared with other ethnic groups. They also present with increased rates and earlier onset of diabetes compared with other ethnicities. They have a higher incidence of abdominal obesity, insulin resistance, and dyslipidemia at a lower body mass index and waist circumference. The purpose of this review is to examine the impact of CVD lifestyle interventions in SAs. Two authors independently extracted the data and assessed the quality of each article using the Effective Public Health Practice Project Quality Assessment Tool for Quantitative Studies. Of the 14 studies, 2 studies focused on dietary interventions, two focused on exercise, eight studies employed a combination of the two interventions, and two articles using a multimedia approach to this group. Interventions showed mixed success in reducing modifiable risk factors that led to CVD. Researchers strongly supported the feasibility and effectiveness of using community health workers, community and/or faith-based settings to deliver CVD risk factor reduction interventions in diverse SA groups. With only 14 studies published using culturally tailored interventions to reduce CVD in SAs, there is an obvious gap in the literature targeting modifiable risk factors in this population.
\end{abstract}

\section{Introduction}

The mortality rates for cardiovascular diseases (CVD) have declined in the United States (U.S.) in the past three decades, due to advances in risk factor reduction interventions at individual, community, and national levels [1]. The decline in mortality, however, has not been as significant for minority populations [2], including South Asians [2]. South Asians (SAs) have origins on the Indian sub-continent (India, Pakistan, Bangladesh, Sri Lanka, \& Nepal) and over the last decade, they have become the fastest growing major ethnic group in the U.S [3]. SAs in the U.S. suffer from earlier onset [2] of CVD and have a 3 to 5 -fold increased risk of CVD mortality compared with other ethnic groups [4]. South Asians also present with increased rates and earlier onset of diabetes compared with other ethnicities [5]. South Asians' traditional (atherogenic) diet is rich in saturated fat, trans-fats, salt, and refined carbohydrates that coupled with a sedentary lifestyle and high stress level leaves SAs susceptible to increased CVD risk [6,7]. Comparatively, they have a higher incidence of abdominal obesity, insulin resistance, and dyslipidemia at a lower body mass index (BMI) and waist circumference [2].

Considering this, the World Health Organization (WHO) has recommended lower cut points of $\geq 23 \mathrm{~kg} / \mathrm{m}^{2}$ for overweight and $\geq 27.5 \mathrm{~kg} / \mathrm{m}^{2}$ for obesity compared to $\geq 25 \mathrm{~kg} / \mathrm{m}^{2}$ and $\geq 30 \mathrm{~kg} / \mathrm{m}^{2}$ in the general population [8]. In addition, the International Diabetic Federation has recommended a lower waist circumference (WC) of $\leq 90 \mathrm{~cm}$ for males and $\leq 80 \mathrm{~cm}$ for females as compared to $\leq 102$ $\mathrm{cm}$ and $\leq 88 \mathrm{~cm}$ in the general population [9]. Chiu et al. [10] in their multiethnic cohort study of 59,824 participants, reported the risk of diabetes was significantly higher among SAs, followed by Black, and Chinese at lower ranges of BMI than their White counterparts. The authors further reported that higher level of education seemed to be protective against whereas duration of residence in western countries increased the risk of diabetes. Araneta et al. [11] have consolidated data from 1,663 Asian-Americans community-based studies (which included SAs), this data supported that limiting screening at BMI $\geq 25 \mathrm{~kg} / \mathrm{m}^{2}$ would miss $36 \%$ of diabetes in Asian as compared to $\sim 15 \%$ at BMI $\geq 23 \mathrm{~kg} / \mathrm{m}^{2}$. Therefore, based on the increased risk of CVD at values lower than current recommendations, interventions targeting CVD prevention need to be implemented earlier in SAs.

The purpose of this review was to consolidate the literature and summarize the impact of culturally tailored lifestyle and behavior modification interventions tailored to reduce CVD risk factor in SAs.

\section{Methods}

The scoping review was performed by searching the PUBMED, CINAHL, and Web of Science databases to identify publications of ethnically specific CVD prevention interventions on SA adults, which were written in English from January 1995 through January 2017. A combination of the following keywords was used: South Asian, cardiovascular disease risk factors, self-management, health behavior changes and lifestyle intervention. Only articles that met this inclusion criteria that focused on interventional studies in the South Asians were included. A total of 132 articles were found in the search, 25 duplicate articles were removed and 94 were excluded. A total of 14 articles were used for this review. Two authors independently assessed the quality of each article using the Effective Public Health Practice Project Quality Assessment Tool for Quantitative Studies [12]. According to the tool, eight studies were classified as strong, four as moderate, and two as weak. Disagreements between reviewers were resolved through discussion (Table 1).

${ }^{*}$ Correspondence to: Rozmin Jiwani, Assistant Professor of Nursing at the UT Health San Antonio, 7703 Floyd Curl Drive, San Antonio, TX, USA

Key words: icardiovascular disease risk factors, lifestyle intervention, health behavior change intervention, South Asian, and self-management

Received: June 09, 2018; Accepted: June 20, 2018; Published: June 22, 2018 
Table 1. Presents a synthesis of the 14 studies.

\begin{tabular}{|c|c|c|c|c|c|}
\hline $\begin{array}{l}\text { Year, } 1^{\text {st }} \text { Author } \\
\text { last name, country }\end{array}$ & $\begin{array}{l}\text { Participant } \\
\text { Demographics }\end{array}$ & $\begin{array}{l}\text { Study } \\
\text { Focus } \\
\text { Design }\end{array}$ & Intervention & $\begin{array}{l}\text { Key } \\
\text { Findings }\end{array}$ & EPHPP Score \\
\hline $\begin{array}{l}\text { 2016, Anand, } \\
\text { Canada }\end{array}$ & $\begin{array}{l}\mathrm{N}=343 \\
51.9 \% \text { Male } \\
\text { Pts from SA countries }\end{array}$ & $\begin{array}{l}\text { Diet/Exercise } \\
\text { Single-blind } \\
\text { randomized }\end{array}$ & $\begin{array}{l}\text { Email/Text messages (digital } \\
\text { intervention) sent to increase knowledge } \\
\text { of diet/exercise, as well as personally } \\
\text { tailored genetic risk factors (Intervention } \\
\text { lasted for 1year]. }\end{array}$ & $\begin{array}{l}\text { The digital intervention was not found to be significantly } \\
\text { effective. } \\
\text { Retention rate: } 98 \%\end{array}$ & Moderate \\
\hline $\begin{array}{l}\text { 2016, Guess, } \\
\text { Sri Lanka }\end{array}$ & $\begin{array}{l}\mathrm{N}=4683 \\
52.3 \% \text { Female } \\
\text { Pts from Sri-Lanka }\end{array}$ & $\begin{array}{l}\text { Diet/Exercise } \\
\text { RCT }\end{array}$ & $\begin{array}{l}\text { Intervention arm: telephone and/or } \\
\text { face-to-face contact } 4 \text { per year, intensive } \\
\text { lifestyle advice. Interventions tailored to } \\
\text { Sri-Lankan SA group. } \\
\text { Control arm: Same lifestyle advice, but } \\
\text { one face-to-face contact per year. } \\
\text { (Intervention lasted for } 5 \text { years]. }\end{array}$ & $\begin{array}{l}\text { Significantly improved BMI, WC, and FBG in participants } \\
\text { who followed the lifestyle advice. } \\
\text { Retention rate: } 56 \%\end{array}$ & Weak \\
\hline 2016, Willis, UK & $\begin{array}{l}\mathrm{N}=252 \text { screened. } \\
\mathrm{n}=32 \text { invited with } \\
>\mathrm{HbA} 1 \mathrm{c} . \\
\mathrm{n}=18 \text { attended. } \\
\% \text { Not reported } \\
\text { Pts from SA countries }\end{array}$ & $\begin{array}{l}\text { Diet/Exercise } \\
\text { Single Arm }\end{array}$ & $\begin{array}{l}\text { Initial screening lasted for } 4 \text { weeks. } \\
\text { Supplied pedometer to encourage } \\
\text { walking. Group education sessions } \\
\text { for participants with HbA1c } 6-6.4 \% \text {. } \\
\text { Educational sessions held at the faith } \\
\text { center using CHW for } 4 \text { weeks. } \\
\text { (Intervention lasted for } 4 \text {-weeks]. }\end{array}$ & $\begin{array}{l}\text { Suggests the higher attendance for this study educational } \\
\text { sessions may be using faith-based centers and CHW during } \\
\text { the screening and educational sessions. } \\
\text { Retention rate: } 56 \%\end{array}$ & Moderate \\
\hline $\begin{array}{l}\text { 2015, Kandula, } \\
\text { USA }\end{array}$ & $\begin{array}{l}\mathrm{N}=63 \\
63 \% \text { Female } \\
\text { Pts from India \& } \\
\text { Pakistan }\end{array}$ & $\begin{array}{l}\text { Diet/Exercise } \\
\text { RCT }\end{array}$ & $\begin{array}{l}\text { Intervention arm: } 6 \text { weeks of culturally } \\
\text { tailored group education classes, } \\
\text { pedometers, follow-up telephone calls for } \\
6 \text { months. } \\
\text { Control arm: received printed educational } \\
\text { materials. } \\
\text { (Intervention lasted for } 6 \text { months]. }\end{array}$ & $\begin{array}{l}\text { Significant improved } \mathrm{HbAlc} \text { and Weight } \\
\text { Retention rate: } 100 \%\end{array}$ & Moderate \\
\hline 2015, Shah, USA & $\begin{array}{l}\mathrm{N}=112 \\
\% \text { Not reported } \\
\text { Pts from India \& } \\
\text { Pakistan }\end{array}$ & $\begin{array}{l}\text { Diet/Exercise } \\
\text { Cross-sectional }\end{array}$ & $\begin{array}{l}\text { Surveys were given to ascertain the } \\
\text { participant's knowledge/perceptions } \\
\text { of cardiovascular health- both pre/post } \\
\text { multimedia education programs. } \\
\text { [Cross-sectional study] }\end{array}$ & $\begin{array}{l}\text { Significantly improved knowledge and perceptions about } \\
\text { CVD prevention among SAs. } \\
\text { Retention rate: cross-sectional study }\end{array}$ & Strong \\
\hline 2014, Bhopal, UK & $\begin{array}{l}\mathrm{N}=171 \\
\% \text { Not reported } \\
\text { Pts from India \& } \\
\text { Pakistan }\end{array}$ & $\begin{array}{l}\text { Diet/Exercise } \\
\text { RCT }\end{array}$ & $\begin{array}{l}\text { Intervention arm: } 15 \text { visits from a } \\
\text { dietitian for } 3 \text { years. } \\
\text { Control arm: } 4 \text { visits from a dietician, the } \\
\text { standardized material in the same time } \\
\text { period (for } 3 \text { years). } \\
\text { (Intervention lasted for } 3 \text { years]. }\end{array}$ & $\begin{array}{l}\text { Intervention group exhibited significantly reduced weight, } \\
\text { BMI, WC and hip circumference. Physical activity } \\
\text { increased for both groups. Progression to T2DM reduced in } \\
\text { the intervention group. } \\
\text { Retention rate: } 98 \%\end{array}$ & Strong \\
\hline 2014, Gany, USA & $\begin{array}{l}\mathrm{N}=74 \\
100 \% \text { Male } \\
\text { Pts from SA countries }\end{array}$ & $\begin{array}{l}\text { Exercise } \\
\text { Single Arm }\end{array}$ & $\begin{array}{l}\text { Pedometers and written material for } \\
\text { lowering CVD risk factor for } 3 \text { months. } \\
\text { (Intervention lasted for } 3 \text { months]. }\end{array}$ & $\begin{array}{l}\text { Overall, a small (non-significant) increase in daily step } \\
\text { count of among the study participants. } \\
\text { Retention rate: } 39 \%\end{array}$ & Strong \\
\hline 2014, Islam, USA & $\begin{array}{l}\mathrm{N}=126 \\
81 \% \text { Female } \\
\text { Pts from Indian-Sikh } \\
\text { community }\end{array}$ & $\begin{array}{l}\text { Diet/Exercise } \\
\text { Dual } \\
\text { Arm }\end{array}$ & $\begin{array}{l}\text { Both arms: } 6 \text { total workshops, instruction/ } \\
\text { education led by CHW in Sikh Indian } \\
\text { group } \\
\text { Intervention arm: } 10 \text { calls over } 6 \text { months } \\
\text { and provided individual recommendations } \\
\text { regarding diet/exercise/stress reduction. } \\
\text { [Intervention lasted for } 6 \text { months] }\end{array}$ & $\begin{array}{l}\text { Intervention arm: Significant changes in weight, BMI, WC, } \\
\text { BP, glucose, cholesterol, health behaviors and diabetes } \\
\text { knowledge. } \\
\text { Between-group differences were significant for glucose, } \\
\text { diabetes knowledge, portion control, and physical activity/ } \\
\text { social integration. } \\
\text { Retention rate: } 86 \%\end{array}$ & Strong \\
\hline $\begin{array}{l}\text { 2013, Admiraal, } \\
\text { Netherlands }\end{array}$ & $\begin{array}{l}\mathrm{N}=536 \\
51 \% \text { Male } \\
\text { Pts from India }\end{array}$ & $\begin{array}{l}\text { Diet/Exercise } \\
\text { RCT }\end{array}$ & $\begin{array}{l}\text { Intervention arm: } 6-8 \text { counseling sessions } \\
\text { in the first } 6 \text { months, followed by } 2 \\
\text { "booster sessions" in the following } 6 \\
\text { months. Family session, cooking classes, } \\
\text { and supervised physical activity program } \\
\text { offered by a culturally trained dietician. } \\
\text { Control arm: Rec'd generic lifestyle advice. } \\
\text { (Intervention lasted for 1year] }\end{array}$ & $\begin{array}{l}\text { Targeted interventions did not result in significant } \\
\text { improvement of weight status/metabolic profile after } 1 \text { year. } \\
\text { Retention rate: } 38 \%\end{array}$ & Strong \\
\hline 2013, Islam, USA & $\begin{array}{l}\mathrm{N}=26 \\
58 \% \text { Female } \\
\text { Pts from Bangladesh }\end{array}$ & $\begin{array}{l}\text { Diet/Exercise } \\
\text { Single Arm }\end{array}$ & $\begin{array}{l}6 \text { monthly education sessions using } \\
\text { CHW in Bangladeshi-American with } \\
\text { T2DM (incorporating group exercise), } \\
\text { one-on-one visits to discuss diabetes } \\
\text { management. } \\
\text { (Intervention lasted for } 12 \text { months]. }\end{array}$ & $\begin{array}{l}\text { Significance was noted in regard to measuring self-efficacy } \\
\text { in health care access. } \\
\text { A1C, BMI, and weight values all decreased (not } \\
\text { significantly). Knowledge of diabetes risk factors, } \\
\text { medication compliance, and exercise improved. } \\
\text { Retention rate: } 50 \%\end{array}$ & Moderate \\
\hline $\begin{array}{l}\text { 2012, Andersen, } \\
\text { Norway }\end{array}$ & $\begin{array}{l}\mathrm{N}=150 \\
100 \% \text { Male } \\
\text { Pts from Pakistan }\end{array}$ & $\begin{array}{l}\text { Exercise } \\
\text { RCT }\end{array}$ & $\begin{array}{l}\text { Both arms: Accelerometers } \\
\text { Intervention arm X } 6 \text { months: } 2 / \text { week } \\
\text { community-based structured exercise, } 2 \\
\text { group classes, } 1 \text { individual counseling, } \\
\text { written material, and } 1 \text { telephone f/u. } \\
\text { Control arm X } 6 \text { months: offered } 1 / \text { week } \\
\text { exercise classes, } 1 \text { group lecture, and } \\
\text { written material. } \\
\text { (Intervention lasted for } 6 \text { months and } \\
\text { follow-up call } 6 \text { months after the study). }\end{array}$ & $\begin{array}{l}\text { Intervention arm saw a significant decrease in sedentary } \\
\text { hours per day. } \\
\text { Retention rate: } 89 \%\end{array}$ & Strong \\
\hline
\end{tabular}




\begin{tabular}{|c|c|c|c|c|c|}
\hline 2008, Backes, USA & $\begin{array}{l}\mathrm{N}=23 \\
100 \% \text { Female } \\
\text { Pts from India }\end{array}$ & Diet & $\begin{array}{l}\text { Nutritional counseling from culturally } \\
\text { tailored dietary interventions from } \\
\text { dietitian focusing on a diet consisting } \\
\text { of } 40-45 \% \text { carbohydrates and weekly } \\
\text { weigh-in x } 3 \text { months. } \\
\text { *Exercise was 'encouraged' } \\
\text { (Intervention lasted for } 3 \text { months) }\end{array}$ & $\begin{array}{l}\text { Significant changes found in BMI, FBG, SSPG, and TG. } \\
\text { Retention rate: } 82 \%\end{array}$ & Strong \\
\hline $\begin{array}{l}\text { 2007, Mathews, } \\
\text { UK }\end{array}$ & $\begin{array}{l}\mathrm{N}=304 \\
66.6 \% \text { Female } \\
\text { Pts from India, } \\
\text { Pakistan, Bangladesh, } \\
\text { and other SA } \\
\text { countries. }\end{array}$ & $\begin{array}{l}\text { Diet/Exercise } \\
\text { Non-randomized }\end{array}$ & $\begin{array}{l}\text { Transtheoretical model to assess } \\
\text { stages of change. After the baseline } \\
\text { anthropometrics, blood test, individual } \\
\text { consultation, and goal setting were } \\
\text { conducted in the community. Participants } \\
\text { were invited } 6 \text { months for the follow-up } \\
\text { study. } \\
\text { - (After the baseline assessment and goal } \\
\text { setting, follow-up assessment was done } \\
\text { after } 6 \text { months). }\end{array}$ & $\begin{array}{l}50 \% \text { stated an increase in motivation to change; fat } / \text { salt } \\
\text { intake decreased, physical activity increased. } \\
\text { Significant reductions in weight, BMI, BP, \& TC in the } \\
\text { follow-up sample. } \\
\text { Retention rate: } 46 \%\end{array}$ & Weak \\
\hline 2002, Singh, India & $\begin{array}{l}\mathrm{N}=1000 \\
90 \% \text { Male } \\
\text { Pts from India }\end{array}$ & $\begin{array}{l}\text { Diet } \\
\begin{array}{l}\text { Randomized, } \\
\text { single-blind }\end{array}\end{array}$ & $\begin{array}{l}\text { Intervention arm: Indo-Mediterranean diet. } \\
\text { Control arm: National Cholesterol } \\
\text { Education Program. } \\
\text { (Intervention lasted for } 2 \text { years) }\end{array}$ & $\begin{array}{l}\text { Significant reduction in total cardiac deaths in the } \\
\text { intervention group. Significant reduction in serum } \\
\text { cholesterol and anthropometrics in both groups. } \\
\text { Retention rate: } 98 \%\end{array}$ & Strong \\
\hline
\end{tabular}

\section{Results}

The 14 research studies found in this review approached the challenge of providing 'culturally tailored' interventions. Of the 14 studies, two studies focused solely on dietary interventions, two focused on exercise alone, eight studies employed a combination of the two interventions, and two articles using a multimedia-based approach to provide lifestyle interventions to this ethnic group (Figure 1). Table 1 presents a synthesis of the 14 studies.

\section{Single intervention: Diet}

For SAs, a culturally tailored diet provides a link back to the culture and traditions of their native countries. Dietary interventions are often difficult to sustain but provide an opportunistic modifiable variable. Studies focusing on culturally tailored dietary interventions alone showed significant reductions of CVD risk factors in SAs $[13,14]$. Specifically, dietary interventions found focused on education programs that featured methods to modify culturally traditional ingredients with low fat, low cholesterol-based foods. Backes et al.[13] assessed the efficacy of a 3-month dietary modification program (calorie and carbohydrate-restricted diet) in twenty-three women with ages ranging from $30-65$ years, $\mathrm{BMI} \geq 23 \mathrm{~kg} / \mathrm{m}^{2}$ with no reported history of diabetes or other chronic diseases. In the 3 months following their caloric restriction diet (use olive oil vs. ghee, brown rice vs. white rice, etc.) from a dietician (weekly visit), the cohort showed statistically significant reductions in weight, BMI, fasting blood glucose (FBG), steady state plasma glucose (SSPG), and triglyceride (TG).

While the short-term changes reported by authors are favorable, sustained changes in diet are often difficult to maintain [13]. To investigate this, a 2-year follow-up study by Singh et al. [14] evaluated the effects of Indo-Mediterranean diet vs. the National Cholesterol Education Program (NCEP) diet in SAs with pre-existing coronary artery disease. One thousand SAs were included in this study to measure the impact of diet on disease progression and complications. Although the authors did not specify what specific changes were made to the basic Indo-Mediterranean diet, this diet traditionally comprises increased fruit, nut, vegetables, legumes and whole grains [15]. The NCEP diet recommends consuming lower amounts of saturated fat and cholesterol while increasing soluble fiber intake [16]. Participants in the intervention group were asked to follow the Indi-Mediterranean diet, asked to complete for 1 week a record of food intake and physical activity, and followed-up at the regular intervals. Those that consumed

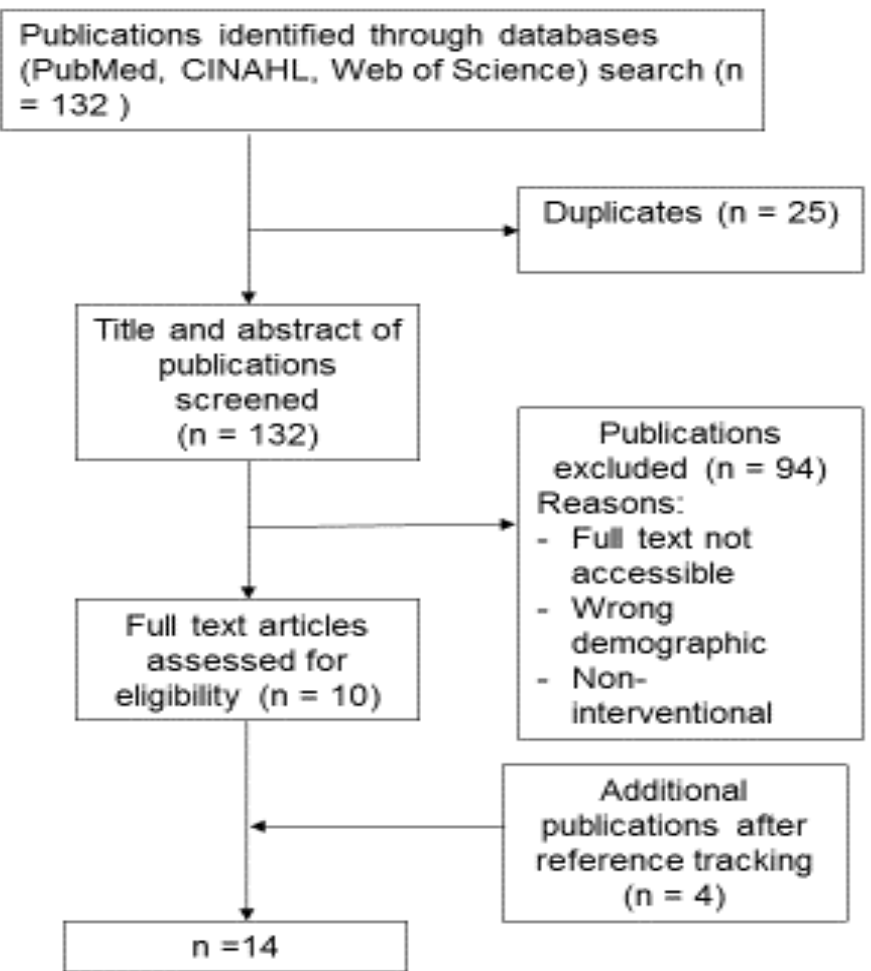

Figure 1. Presents a synthesis of the 14 studies.

the modified Indo-Mediterranean diet presented with significantly lower CVD events over the length of the study compared with the NCEP diet group. Both Backes et al. [13] and Singh et al. [14] supported the overall effect of instituting dietary modifications to reduce CVD risk factors in this population.

\section{Single intervention: Physical activity}

To measure the impact of physical activity, a pilot study was conducted by Gany et al.[17] of otherwise sedentary SA taxi drivers over a 12-week span. Seventy-four participants with elevated CVD risk factors were issued pedometers to increase their daily step counts and to measure the potential impact of intervention on this high-risk population. Comprehensive intake and exit health questionnaires and health screenings (BP, BMI, cholesterol, glucose) were administered. 
Baseline daily step counts were recorded starting four days after the initial screening. At the 4, 8, and 12-week points, step counts were recorded. Overall, the step count intervention resulted in a small (nonsignificant) increase in daily step count of among the 29 participants that completed the program. However, when data was stratified for mediating variables, Gany et al. [17] found significant increases in physical activity in men who were married, suggesting that partner support may be relevant mediator for increased physical activity in this cohort.

In accordance, a longitudinal randomized control trial study on sedentary participants accomplished by Andersen et al. [18] reported significant improvements in physical activity over six months using a community-based intervention. The intervention group received structured group exercise 60-minutes, twice a week, two group lectures, once individual counseling, written material, and a followup phone call 6 month after the study. The control group was offered organized exercise once a week for four months, one group lecture, and written material. Both study groups received accelerometers to track daily activity. Participants were followed-up at six months after the completion of interventions to measure the long-term effects of physical activity. Significant changes in physical activity were found between both arms, with the intervention arm raising the level, as well as the intensity of their physical activity.

Work by both Andersen et al. [18] and Gany et al. [17] showed promising trends in reducing CVD risk factors in SAs through exercise alone. Andersen et al. [18] reported significant decreases in total time spent sedentary with a higher participants retention rate. However, the association between activity levels and anthropometric or serum values were not discussed. Gany et al. [17] had less success in motivating participants to decrease their sedentary time while working with varied work schedules. One reported limitation of the study was that contacting the participants was difficult, as their work, environment, and schedule did not make telephone contact consistent.

\section{Mixed interventions using community health workers}

Ten studies used patient education and motivation with either trained community health workers (CHW) or dieticians in a community and/or faith-based settings. Willis et al. [19] studied the use of $\mathrm{CHW}$ to deliver educational interventions at the faith-based center to participants at high risk for type 2 Diabetes Mellitus (T2DM). After the initial screening, the authors invited 32 participants at high risk for T2DM to attend weekly group educational sessions for up to 4 weeks; however, only 18 (56.3\%) participants completed the sessions. The authors reported that using $\mathrm{CHW}$ was both feasible and effective in facilitating high numbers of screening, teaching, and the setting supported to be advantageous regarding participant attendance. Some of the limitations of this study are a small number of participants completed the study and authors did not report changes in CVD risk factors.

To further understand the cultural differences between SA groups and the efficacy of CHW interventions, Islam and colleagues published that were conducted on two different SA groups with T2DM [20,21]. The first study [20] investigated the use of CHW on CVD risk factors in Bangladeshi-Americans with T2DM. Six monthly CHW facilitated sessions were performed on the topic of diabetes management. Surveys were conducted at baseline, 3, 6, 9, and 12-months. Improvements were seen in diabetes knowledge, self-efficacy of exercise, diet, medication compliance, a decrease in AIC, and BMI. Another study by Islam et al. [21] on a Sikh Indian community the authors implemented the existing U.S. Diabetes Prevention Program [22]. Of 126 enrolled participants,
108 completing the study surveys at baseline and at 6-months [21]. The authors reported significant improvements in the clinical variables (weight, BMI, WC, BP, FBG, and cholesterol) and health behaviors (physical activity, dietary choices, and diabetes knowledge) were significant.

Guess et al. [23] examined the effect of intensive dietary modifications over a period of 5 years in SAs from Sri-Lanka with two or more well-defined CVD risk factors. Participants in the treatment group received three monthly telephone and/or face-to-face contacts (4 per year) to assess their progress and to reiterate goals. Participants in the control group received the same advice, but only one face-toface contact per year. Lifestyle advice was based on the Indian Diabetes Prevention Program, [24] which include balancing food intake (i.e., replacing sugar/refined carbohydrates with fiber-rich food and reducing total fat intake) and increased physical activity. The authors reported that the participants who followed the dietary regimen reduced their BMI, WC, and FBG [23].

The above four studies showed the feasibility and acceptance of $\mathrm{CHW}$ led education in different SA groups. All four studies strongly supported the feasibility and effectiveness of using CHW to deliver CVD risk factor reduction interventions for different SA groups. The reported retention rate was also $50 \%$ and higher for the above studies.

Admiraal et al. [25] focused on a single subset of the SA population (Hindustani Surinamese) where culturally proficient dietitians provided dietary counseling. Unfortunately, no statically significant changes in the participants' anthropometric or serum profile were reported with a high dropout rate. Bhopal et al. [26] study had the distinction of intervention being delivered at home by a dietitian over a 3-year period. The authors recruited $171 \mathrm{SA}$ participants, aged $\geq 35$ years, with $\mathrm{WC} \geq 90 \mathrm{~cm}$ for male and $\geq 80 \mathrm{~cm}$ for female, and with impaired glucose tolerance. The study allowed for up to 15 home visits over a three-year period. The participants were asked to complete a 3-day food diary and measure their physical activity with a provided pedometer. The authors concluded that the participants in the intervention group exhibited significantly reduced weight, BMI, waist and hip circumference (primary outcome of the study). Physical activity was increased over baseline for both groups, but the difference was not statistically significant. The secondary outcome, 'progression to T2DM' was observed less frequently in the intervention group.

A longitudinal study conducted by Mathews et al. [27] in several SA community settings where participants attended initial health screening, including blood tests. Participants had a follow-up visit to discuss their blood tests and to set goals related to healthy diet, physical exercise, stress management, and others. At a 6-month follow, authors measured the change in behaviors and motivation to achieve the set goals using the Transtheoretical model of change. Authors reported a significant reduction in participants' weight, BP, TC, and several positive self-reported behaviors changes such as increasing physical activity and using healthier cooking methods. Similarly, Kandula et al. [28] focused on reducing CVD risk factors by increasing physical activity and instituting a healthy diet with the goal of reducing weight and stress. The authors reported that the intervention group achieved a significant decrease in weight and $\mathrm{HbAlc}$ compared to the control group at 6-months. The authors reported no significant difference between both arms regarding BP, dietary modification, TC, FBG, or psychosocial outcomes. With this pilot study $(n=63)$ the researchers could involve the medically underserved community and evaluate the significant impact of intensive hands-on educational instructions and exercise classes on the study participants. 


\section{Interventions using Technology}

Two studies reported the use of novel approaches using technology-based approaches to reducing CVD risk factors in SAs. Shah et al. [29] reported the effectiveness of using multimedia health education on participants' knowledge on 112 SAs across different language, education, and acculturation levels. The authors measured participants' CVD risk factors knowledge using pre, post questionnaire and concluded that post-test score of study participants significantly improved, including those with limited English proficiency. To integrate digital health interventions into the lives of SAs, Anand et al. [30] aimed to educate the target SA population, free of CVD, in regard to their personal genetic risk of developing CVD, as well as attempting to encourage the individual to modify physical activity and dietary intake. This was accomplished by sending bi-weekly emails or weekly text messages based on the participants preferred a mode of communication. Researchers focused on $\mathrm{BP}$, waist to hip ratio, $\mathrm{HbAlc}$, and apolipoprotein $\mathrm{A} / \mathrm{B}$ ratios. The researcher reported that neither the digital interventions nor the knowledge of the participant's MI risk factor showed significant positive change to prevent CVD. Some of the reasons for non-significant findings could be that the authors have recruited participants who were free of CVD, reported already physically active and were involved in dietary modification. It might be helpful to follow these participants longer than 1 year to measure the impact of digital health interventions in this ethnic group.

\section{Discussion}

The SA populations' propensity to develop CVD at an earlier age [2] and at anthropometric values (weight/BMI, WC) that are considered 'healthy' by many experts is but one challenge in dealing with this ethnic group [11]. The SA community is very diverse with over 7 countries represented with each having multiple cultural and religious subgroups [3]. However, a common thread connecting all SAs is the atherogenic diet, sedentary lifestyle, and premature morbidity and mortality related to CVD risk factors.

The purpose of our review was to identify and collect the impact of culturally tailored lifestyle and behavior modification interventions tailored to reduce CVD risk factor in the diverse SA community. In our review, studies instituting dietary modifications and/or physical activity resulted in reduced CVD risk factors in this population. In addition, several studies in our review using mixed interventions of either diet and exercise reported positive outcomes. In line with this review, other reviews have also recommended offering patients with established CVD as well as individuals and communities at high risk of CVD comprehensive lifestyle advice as part of their medical treatment [31-33].

Mixed intervention studies found in this review also supported the benefits of using trained $\mathrm{CHW}$, community and/or faith-based settings as they were effective in facilitating high numbers of screening, implementing teaching interventions, and to be advantageous in regard to participant attendance and retention. This is consistent with other studies conducted on ethnic minority groups where authors have supported that using CHW can be an effective and cost-saving strategy to provide culturally tailored behavior change interventions [34-36]. The results of this literature review suggest that $\mathrm{CHW}$ can serve as partners in health to build trust and rapport, to provide social support, improves recruitment, retention, and engagement to assist with health behavior change, but we have not been able to quantify effects of clinical outcomes.
To connect to the various subgroups in the SA community, the use of community setting and/or CHW embedded in the various subgroups has the potential to make significant changes in CVD risk in this population. In fact, community setting, faith-based center and $\mathrm{CHW}$ led intervention helped overcome barriers and facilitated program outcomes. This was accomplished through a communal concordance, trust, and leadership in several diverse SA communities. Participants gave positive feedback as educational instructions were provided in lay terminologies by trained CHW. In addition, the authors accommodated participants' schedules by offering additional sessions at convenient times, a method that helped ensure high retention rates for this group. The use of trained $\mathrm{CHW}$ to deliver education and intervention is strength and warrants further exploration by the scientific community.

Further, the lack of large scale multisite studies limits the generalizability of published reports. Future work must integrate large scale clinical trials recruiting participants from across the SA countries to test multifactorial interventions. The lack of equal gender representation is a significant limitation to the studies presented in this review providing a significant gap that needs to be filled. In the SA community, females are often the family members tasked with the cooking but are also not exempt from the high CVD risk presented in this paper. Thus, SA females represent are a significant segment of the population that needs to be included in future work. This review may help researchers to develop and test multidimensional longitudinal behavior change intervention using $\mathrm{CHW}$ or community and/or faithbased settings to lower CVD related morbidity and mortality in this ethnic group. Future research should delve into the psychological aspects of how SA's learn the most effectively and increasing retention across the religion and genders could be how the SA population is reached and treated in the most effective way possible.

\section{Conclusion}

The results of this review provide foundational evidence to the effects of culturally competent interventions to improve CVD risk factors in the SA community. However, the limited number of articles found suggest significant work is still needed to make impactful changes in reducing CVD risk factors and improving outcomes in this highly vulnerable population. We recommend the use of trained $\mathrm{CHW}$ as 'agent of change' in the implementation of culturally tailored interventions within the SA community. The researcher may train $\mathrm{CHW}$, as supported the best research approach from this review, where trained $\mathrm{CHW}$ will deliver culturally tailored multidimensional behavior modification interventions.

\section{References}

1. Mozaffarian D, Benjamin EJ, Go AS, Arnett DK, Blaha MJ, et al. (2015) Heart disease and stroke statistics--2015 update: a report from the American Heart Association. Circulation 131: e29-322. [Crossref]

2. Yusuf S, Hawken S, Ounpuu S, Dans T, Avezum A (2004) Effect of potentially modifiable risk factors associated with myocardial infarction in 52 countries (the INTERHEART study): case-control study. Lancet 364: 937-952. [Crossref]

3. South Asian American LeadingTogether (2015) A demographic snapshot of South Asians in the United States. Saalt.

4. Anand SS1, Yusuf S, Vuksan V, Devanesen S, Teo KK, et al. (2000) Differences in risk factors, atherosclerosis and cardiovascular disease between ethnic groups in Canada: the study of health assessment and risk in ethnic groups (SHARE). Lancet 279-284 [Crossref]

5. Kanaya AM, Kandula N, Herrington D, Budoff MJ, Hulley S, et al. (2013) Mediators of Atherosclerosis in South Asians Living in America (MASALA) Study: Objectives, Methods, and Cohort Description. Clinical cardiology 36: 713-720. [Crossref] 
6. Gadgil MD, Anderson CA, Kandula NR, Kanaya AM (2014) Dietary patterns in Asian Indians in the United States: an analysis of the metabolic syndrome and atherosclerosis in South Asians Living in America study. J Acad Nutr Diet 114: 238-243. [Crossref]

7. Gujral UP, Narayan KM, Pradeepa RG, Deepa M, Ali MK, et al. (2015) Comparing Type 2 Diabetes, Prediabetes, and Their Associated Risk Factors in Asian Indians in India and in the U.S.: The CARRS and MASALA Studies. Diabetes care 38: 13121318. [Crossref]

8. World Health Organization Expert Consultation (2004) Appropriate body-mass index for Asian populations and its implications for policy and intervention strategies. Lancet 363: 157-163. [Crossref]

9. Alberti KG, Zimmet P, Shaw J (2007) International Diabetes Federation: a consensus on Type 2 diabetes prevention. Diabet Med 24: 451-463. [Crossref]

10. Chiu M, Austin PC, Manuel DG, Shah BR, Tu JV (2011) Deriving ethnic-specific BMI cutoff points for assessing diabetes risk. Diabetes Care 34: 1741-1748. [Crossref]

11. Araneta MR, Kanaya AM, Hsu WC, Chang HK4, Grandinetti A, et al. (2015) Optimum BMI cut points to screen asian americans for type 2 diabetes. Diabetes Care 38: 814820. [Crossref]

12. Thomas BH, Ciliska D, Dobbins M, Micucci S (2004) A process for systematically reviewing the literature: providing the research evidence for public health nursing interventions. Worldviews Evid Based Nurs 1: 176-184. [Crossref]

13. Backes AC, Abbasi F, Lamendola C, McLaughlin TL, Reaven G, et al. (2008) Clinical experience with a relatively low carbohydrate, calorie-restricted diet improves insulin sensitivity and associated metabolic abnormalities in overweight, insulin resistant South Asian Indian women. Asia Pac J Clin Nutr 17: 669-671. [Crossref]

14. Singh RB, Dubnov G, Niaz MA, Ghosh S, Singh R, et al. (2002) Effect of an IndoMediterranean diet on progression of coronary artery disease in high risk patients (Indo-Mediterranean Diet Heart Study): a randomised single-blind trial. Lancet 360: 1455-1461. [Crossref]

15. Kris-Etherton P, Eckel RH, Howard BV, St Jeor S, Bazzarre TL (2001) AHA Science Advisory: Lyon Diet Heart Study. Benefits of a Mediterranean-style, National Cholesterol Education Program/American Heart Association Step I Dietary Pattern on Cardiovascular Disease. Circulation 103: 1823-1825. [Crossref]

16. Grundy SM, Cleeman JI, Merz CN, Brewer HB Jr, Clark LT, et al. (2004) Implications of recent clinical trials for the National Cholesterol Education Program Adult Treatment Panel III Guidelines. Circulation 110: 227-39. [Crossref]

17. Gany F, Gill P, Baser R, Leng J (2014) Supporting South Asian Taxi Drivers to Exercise through Pedometers (SSTEP) to decrease cardiovascular disease risk. $J$ Urban Health 91: 463-476. [Crossref]

18. Andersen E, Burton NW, Anderssen SA (2012) Physical activity levels six months after a randomised controlled physical activity intervention for Pakistani immigrant men living in Norway. Int J Behav Nutr Phys Act 9: 47. [Crossref]

19. Willis A, Roshan M, Patel N, Gray LJ, Yates T, et al. (2016) A community faith centre based screening and educational intervention to reduce the risk of type 2 diabetes: A feasibility study. Diabetes Res Clin Pract 120: 73-80. [Crossref]

20. Islam NS, Wyatt LC, Patel SD, Shapiro E, Tandon SD, et al. (2013) Evaluation of a community health worker pilot intervention to improve diabetes management in Bangladeshi immigrants with type 2 diabetes in New York City. Diabetes Educ 39: 478-493. [Crossref]

21. Islam NS, Zanowiak JM, Wyatt LC, Kavathe R, Singh H, et al. (2014) Diabetes Prevention in the New York City Sikh Asian Indian Community: A Pilot Study. Int $J$ Environ Res Public Health 11: 5462-5486. [Crossref]
22. Kramer MK, Miller RG, Siminerio LM (2014) Evaluation of a community Diabetes Prevention Program delivered by diabetes educators in the United States: one-year follow up. Diabetes Res Clin Pract 106: e49-52.

23. Guess N, Wijesuriya M, Vasantharajah L, Gulliford M, Viberti G, et al. (2016) The effect of dietary changes on distinct components of the metabolic syndrome in a young Sri Lankan population at high risk of CVD. Br J Nutr;116: 719-727. [Crossref]

24. Ramachandran A, Snehalatha C, Mary S, Mukesh B, Bhaskar AD, et al. (2006) The Indian Diabetes Prevention Programme shows that lifestyle modification and metformin prevent type 2 diabetes in Asian Indian subjects with impaired glucose tolerance (IDPP-1). Diabetologia 49: 289-297. [Crossref]

25. Admiraal WM, Vlaar EM, Nierkens V, Holleman F, Middelkoop BJ, et al. (2013) Intensive Lifestyle Intervention in General Practice to Prevent Type 2 Diabetes among 18 to 60-Year-Old South Asians: 1-Year Effects on the Weight Status and Metabolic Profile of Participants in a Randomized Controlled Trial. Plos One 8: 10. [Crossref]

26. Bhopal RS, Douglas A, Wallia S, Forbes JF, Lean ME, et al. (2014) Effect of a lifestyle intervention on weight change in south Asian individuals in the UK at high risk of type 2 diabetes: a family-cluster randomised controlled trial. Lancet Diabetes Endocrinol 2: 218-227. [Crossref]

27. Mathews G, Alexander J, Rahemtulla T, Bhopal R (2007) Impact of a cardiovascular risk control project for South Asians (Khush Dil) on motivation, behaviour, obesity, blood pressure and lipids. J Public Health (Oxf) 29: 388-397. [Crossref]

28. Namratha R. KandulaEmail author, Swapna Dave, Peter John De Chavez, Himal Bharucha, Yasin Patel, et al. (2015) Translating a heart disease lifestyle intervention into the community: the South Asian Heart Lifestyle Intervention (SAHELI) study; a randomized control trial. BMC Public Health 15: 1064.

29. Shah A, Clayman ML, Glass S, Kandula NR (2015) Protect your heart: a culturespecific multimedia cardiovascular health education program. J Health Commun 20: 424-430. [Crossref]

30. Anand SS, Samaan Z, Middleton C, Irvine J, Desai D, et al. (2016) A Digital Health Intervention to Lower Cardiovascular Risk: A Randomized Clinical Trial. JAMA Cardiol 1: 601-606. [Crossref]

31. Rodrigues AL, Ball J, Ski C, Stewart S, Carrington MJ (2016) A systematic review and meta-analysis of primary prevention programmes to improve cardio-metabolic risk in non-urban communities. Prev Med 87: 22-34. [Crossref]

32. Blokstra A, van Dis I, Verschuren WM (2012) Efficacy of multifactorial lifestyle interventions in patients with established cardiovascular diseases and high risk groups. Eur J Cardiovasc Nurs 11: 97-104. [Crossref]

33. Dagogo-Jack S, Egbuonu N, Edeoga C (2010) Principles and practice of nonpharmacological interventions to reduce cardiometabolic risk. Med Princ Pract 19: 167-175. [Crossref]

34. Katigbak C, Van Devanter N, Islam N, Trinh-Shevrin C (2015) Partners in health: a conceptual framework for the role of community health workers in facilitating patients' adoption of healthy behaviors. Am J Public Health 105: 872-880. [Crossref]

35. Wagner J, Kong S, Kuoch T, Scully MF, Tan HK, Bermudez-Millan A (2015) Patien Reported Outcomes of 'Eat, Walk, Sleep': A Cardiometabolic Lifestyle Program fo Cambodian Americans Delivered by Community Health Workers. $J$ Health Care Poor Underserved 26: 441-452. [Crossref]

36. Baruth M, Wilcox S (2013) Multiple behavior change among church members taking part in the faith, activity, and nutrition program. J Nutr Educ Behav 45: 428-434. [Crossref]

Copyright: (C2018 Jiwani R. This is an open-access article distributed under the terms of the Creative Commons Attribution License, which permits unrestricted use, distribution, and reproduction in any medium, provided the original author and source are credited. 